\title{
自己組織化マップを用いた東北地方太平洋沖地 震に伴う東京における地下水位の変動特性評価 EVALUATION OF CHARACTERISTICS OF GROUNDWATER LEVEL FLUCTUATION IN TOKYO BY THE 2011 OFF THE PACIFIC COAST OF TOHOKU EARTHQUAKE USING SELF-ORGANIZING MAPS
}

\author{
石原成幸 1 ・河村明 2 ・天口英雄 3 ・高崎忠勝 4 ・川合将文 5 \\ Shigeyuki ISHIHARA, Akira KAWAMURA, Hideo AMAGUCHI, \\ Tadakatsu TAKASAKI and Masafumi KAWAI
}

\footnotetext{
1正会員 修(学) 東京都土木技術支援・人材育成センター 技術支援課（†136-0075 東京都江東区新砂1-9-15）

2正会員 工博 首都大学東京 都市環境科学研究科（干192-0397 東京都八王子市南大沢1-1）

3正会員 博(工) 首都大学東京 都市環境科学研究科（干192-0397 東京都八王子市南大沢1-1）

4正会員 博(工) 東京都土木技術支援・人材育成センター 技術支援課（†136-0075 東京都江東区新砂1-9-15） 5 東京都土木技術支援・人材育成センター＼cjkstart技術支援課（†136-0075 東京都江東区新砂1-9-15）
}

\begin{abstract}
Groundwater observation wells have been bored in 40 sites in Tokyo Metropolis. Large fluctuations of unconfined and confined groundwater levels were observed after the 2011 off the Pacific coast of Tohoku earthquake at 98 observation wells in Tokyo. In this study, the characteristics of groundwater level fluctuation caused by the earthquake were evaluated using Self-Organizing Maps (SOM). The SOM has been suggested as a nonlinear classification method. As for the results, the SOM analysis succeeded in visualizing the characteristics of groundwater level fluctuation. Eight fluctuation patterns were identified for the characteristics of unconfined and confined groundwater level fluctuation. In addition, by comparing the results of the SOM with the visual inspection of fluctuation time series, it is shown that the SOM is successfully and objectively almost the same as the fluctuation patterns after the earthquake.
\end{abstract}

Key Words : the 2011 off the Pacific Coast of Tohoku earthquake, groundwater level fluctuation, Tokyo, SOM (Self-Organizing Maps)

\section{1.はじめに}

2011年3月11日14時46分頃，東北地方三陸沖を震源と するモーメントマグニチュード(Mw)9.0の地震となった 東北地方太平洋沖地震（以下「東日本大地震」と記す） により首都圈では，震度5強の摇れが発生した。 また， 同15時15分頃に発生した震度5弱(Mw7.4)の余震のほか, 数多くの余震・余効変動等に伴って液状化を含む様々な 現象が発生し, 地下水位にも特異な変動が観測された. このような地下水位の変動を正確に捉えることは，地盤 沈下や液状化対策，また広く水資源等の把握の観点から 非常に重要である.さらに，地震に伴う急激な地下水位 変動を評価することは、水循環に与える影響を予測する うえからも有効であり, 将来にわたり貴重な知見となる と考える.

北島らは，産業技術総合研究所活断層・地震研究セン
ターにより観測された地下水と東日本大地震との関連性 について，東海・近畿・四国地方を対象地域とした地震 後1日間の地下水位・地下水圧・自噴量の変化について 報告している1)。このほか，東日本大地震後には，日本 各地で地下水位が上昇または低下する現象，温泉水の湯 量が増加または温度上昇等の変化が見られたと報告され ているが2),3), 詳細な地震前後の変動に関する解析は, ほとんどなされていない.

一方，東京地域を対象とした地下水に関する調査・ 研究としては，大別すると地下水そのものの調査 ${ }^{4}$, 地 盤沈下等との関係を対象にした調査 ${ }^{5)}$, 地震前兆予知な どを前提とした地下水変動を対象勿としたものが多い. しかしながら，東日本大地震に伴う不圧・被圧地下水の 水位変動に関する調査・研究は，管見では承知していな い. 唯一，著者らは土木技術支援・人材育成センター （以下「センター」と記す）の地下水位観測システムが 
捉えた東日本大地震を含む1箇月間（2011年3月）の1時 間単位の観測データを用い，目視による時系列変動のみ に基づいた地下水位の変動パターン特性を主観的に抽出 し，その変動パターンを被圧地下水位7パターン，不圧 地下水位3パターンに分類した ${ }^{7}$.

しかし，東日本大地震に伴う地下水位の観測記録は， 非常に希な観測データであり, 比較・検証が難しい状況 にある.このような過去にない複雑な挙動を生じる地下 水位の変動特性の分析には, 主観的なパターン分類によ ることなく，より客観的な解析手法を用いて地下水位の 変動パターンの特徽を集約することが重要である.ここ で，パターン分類手法の一つである自己組織化マップ

(Self-Organizing Maps, 以下「SOM」と記す) は, 他の パターン分類手法に比して複雑なデータの相互関連性を 二次元平面に視覚化して表現できるなど，データ特性の 発見等に優れた点を有している.このため, これまでに 水文・気象分野への適用例 ${ }^{80} \sim 10$ ) 数多く見受けられる. しかしながら，地下水位変動特性への適用例は，管見で は承知していない.

そこで本論文では，センターの地下水位観測システ ムが捉えた東日本大地震を含む2011年3月の1箇月間にお ける1時間単位の観測データを用い, 地震時の被圧・不 圧地下水位の変動特性をSOMにより客観的に評価した。 また，その結果を前述の目視による時系列変動に基づく 主観的な変動パターン特性と比較検討を行うことで，よ り詳細な変動の特徵や分類特性等を明らかにした.

\section{2. 使用したデータ及びSOMの適用}

\section{（1）入カベクトルに用いたデータ}

図-1には，東京都内（島嶼・山地を除く）に設置され ている地下水位観測局とその局番を示した．また表-1に は, 図-1に対応する各観測局の観測井の詳細を示した. 2011年3月には東京電力による計画停電が行われており, 一部の観測データに久測が生じた. このため, 入力デー 夕には，久測の少ない 40 観測局 98 井（被圧 : 85, 不圧 :

13）における次の(a)から(e)の5項目を設定した.

(a) 地震前後の水位差 $(\mathrm{cm}) \quad(\mathrm{H} 23 / 3 / 11$ 16:00 - 同 14:00)

(b) 地震直後と22時間後（12日）の水位差 $(\mathrm{cm})$

(H23/3/12 14:00 - H23/3/11 16:00)

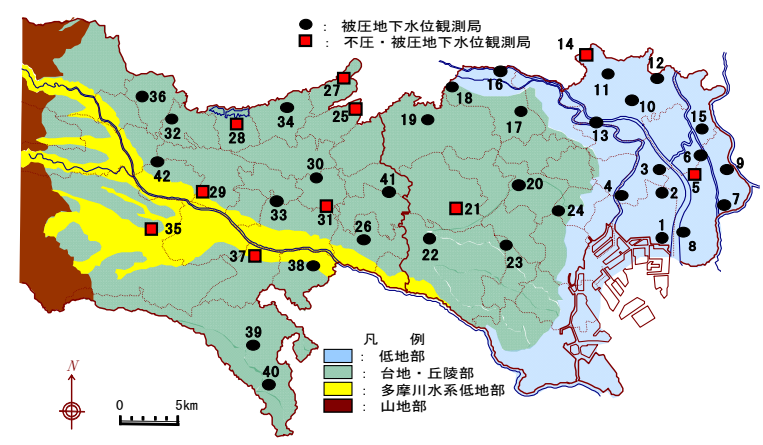

図-1 地下水位観測局の配置状況
表-1 観測井の配置並びに使用データ

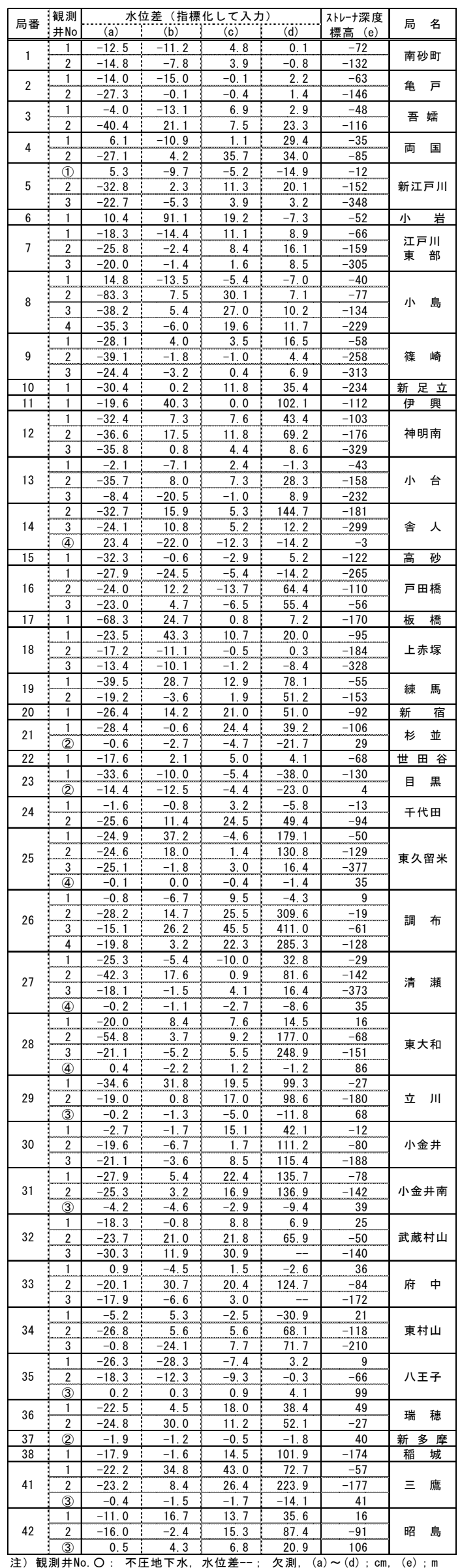


(c) 地震1日後と同2日後（14日）にかけての水位差 $(\mathrm{cm})$ (H23/3/14の日平均值 - H23/3/12 14:00)

(d) 地震2 日後（14日）と3月31日の長期的な水位差 $(\mathrm{cm})$ (H23/3/31の日平均值 $-\mathrm{H} 23 / 3 / 14$ の日平均值)

(e) 各観測井のストレーナ下端深度での標高值(T.P.+m) ストレーナ深度を加味しているのは，SOMにおいて 被圧地下水位と不圧地下水位が精度良く分類されること を念頭に置いているためである.

SOMによる入力ベクトルの選定は，後述するように 入力データ間のユーグリッド距離により組織化される学 習法のため, 分類結果がデータの事前処理に非常に敏感 であることを考慮する必要がある11)。そこで，SOMの 入力ベクトルとしては，表-1に示す生データから, 少数 かつ微少な水位上昇と長期的な変動傾向を抽出できるよ う, 入力データの指標化を行った. 当該指標化に際して は，東日本大地震に伴う東京での地殻変動が最大でも $4 \mathrm{~cm}$ 程度 ${ }^{12)}$ であることを考慮し，前記(a)から(d)に示す地 下水位変動量が士 $5 \mathrm{~cm}$ 末満を $0 ， \pm 5 \mathrm{~cm}$ 以上をそれぞれ +1，-1 とした。 またストレーナ深度は，東京湾中等潮 位による実数值 (単位 : m) で入力した.

\section{(2) SOMの適用}

SOMは，入力したデータの関連性を類似度として マップ上に描画できるニューラルネットワーク手法の一 種である. この機能により，一般的に捉えにくい多次元 のデータを二次元マップ上に分類し，客観的かつ可視的 に表現することができる.

図-2には，今回適用したSOMマップのノード配列を 示す. SOMアルゴリズムでは，入力層から取り出した 入力ベクトル（分類したいデータ）を基に学習すること で，入力ベクトルのパターンを学習する. 各ノード上に 配列されたパターンは，参照ベクトルという多次元ベク トルで表現されており，各ノードには一つの参照ベクト ルが対応している，参照ベクトルは，SOMマップ上で

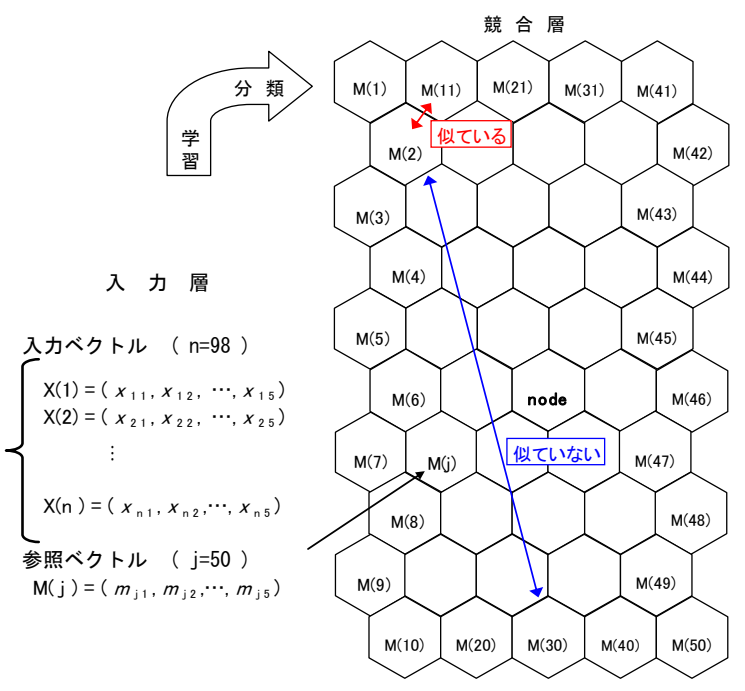

図-2 SOMマップ $(10 \times 5$ ノードの配列)
の距離が互いに近いものほど似ており，距離が遠いもの ほど互いに異なるという性質がある.

次に，マップ上の参照ベクトルのクラスター化を行 う。本研究においては，クラスターの最適数はK-means 法を適用した最小DBI ${ }^{13)}$ （Davies-Bouldin Index）值によ り決定し，クラスター分類にはウォード法 ${ }^{14)}$ を用いた。 SOMの全ノード数 $m$ は，データ数 $n$ に基づいて経験式

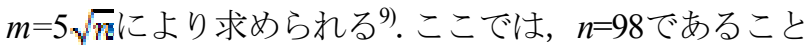
から全ノード数を 50 とし, 図-2に示すように縦 $10 \times$ 横 5 のノード構成とした.

\section{3. 地下水位変動パターンの抽出}

図-3は，SOMを適用して得られた前述の (a)から(e)の 5項目に対する参照ベクトルの結果を示している. 項目 (a)から(d)は，得られた参照ベクトルを[0,1] に基準化し て表し，(e)は得られた参照ベクトルのストレーナ深度 を表している.

次いで，図-3に示された特徵をより容易に把握する ため，50のノードを前述の手法によりクラスター分類し た. 図-4は，クラスター数に対するDBI值の変化を示し たものであり，クラスター分類の最小值は8クラスター と決定される. 図-5は，8つのクラスターの階層とこれ に対応するノード番号を樹形図として示した. また図-6 では各ノードに分類された観測井数をノード中央に示す とともに，分類された8つのクラスターの配置状況を示 した．図一7には，各クラスターの各観測井の特性が容易 に把握できるよう，表-1に示す観測井番号を記した。さ らに図-8には，8つのクラスターの特徵を把握するため, 各クラスターに属する参照ベクトルの值を $[0,1]$ に基準 化し，その第1四分位值，中央值，第3四分位值をプロッ トしたものである.

\section{4. 各クラスターにおける水位変動パターン特性}

\section{（1）SOMIよる地下水位変動のパターン特性分類}

図-3と図-6より，分布パターンの特徴を以下に示す。 なお，今回の解析では基準化したデータを用いて分類し ていることから，分布パターンの詳細には着目せず，そ の大要から特徵を記すものとする.

初めに，図-3の各分布の全般的な特徵としては，上か ら左側4段目と右側5段目を境として上下に，また中央か ら左右で変動特性が大きく異なることが読みとれる.同 図の上段は地震直後に地下水位の低下傾向を示し，時間 の経過とともに上昇傾向が大きくなり，ストレーナ深度 が深いものから比較的浅い観測井までを含んでいる.

左側の中・下段では，3月中旬以降に地下水位の変動 量が大きくなる傾向を有し，ストレーナ深度が大きいも のが分類されている. 右側の中・下段には，不圧地下水 観測井を中心とするストレーナ深度が浅く, 地震直後に 地下水位の上昇傾向を有するものが分類されている. 
（a）水位差

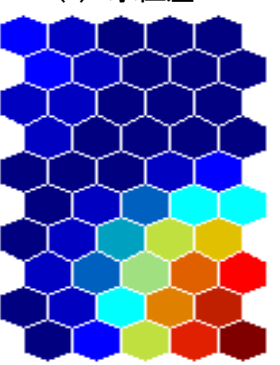

（c）水位差

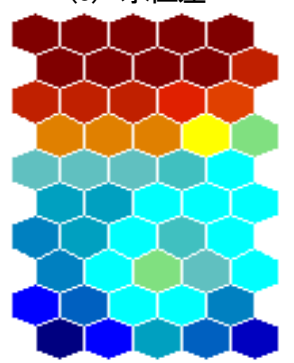

(e) ストレ一ナ深度

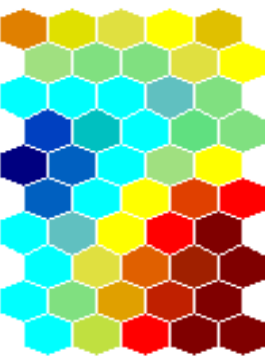

(b) 水位差

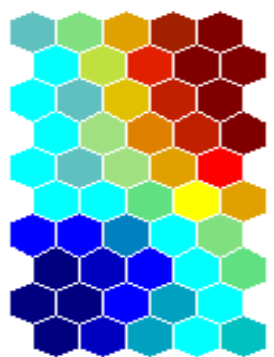

(d) 水位差
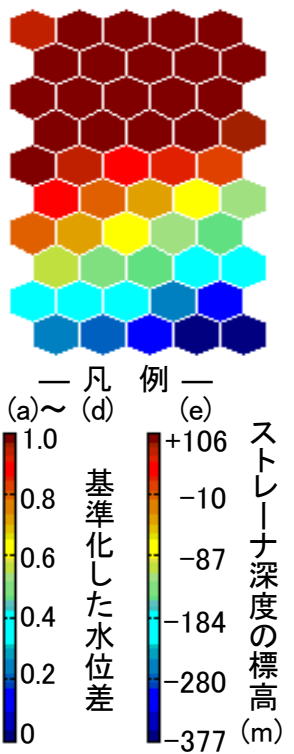

図-3 水位差 $(a) \sim(d)$ と深度 $(e)$ の分布パターン

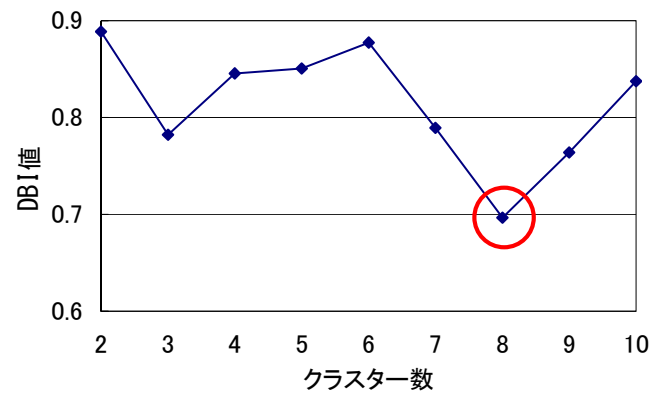

図-4 DBI值とクラスター数の関係

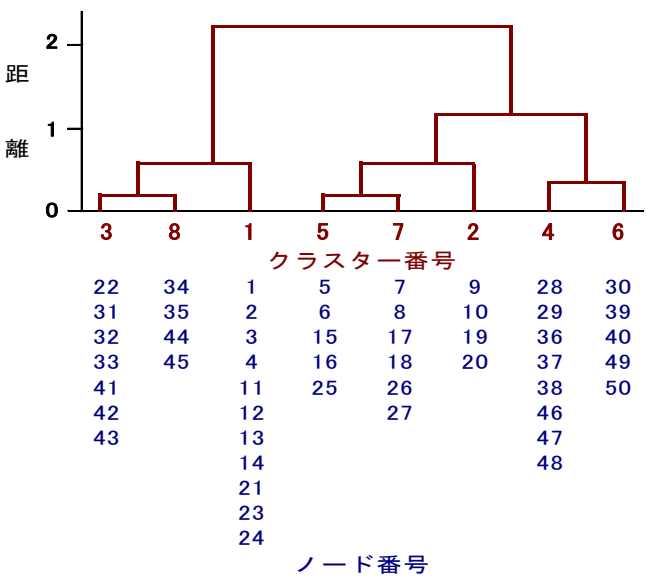

図-5 各クラスターの階層と属するノード（樹形図）

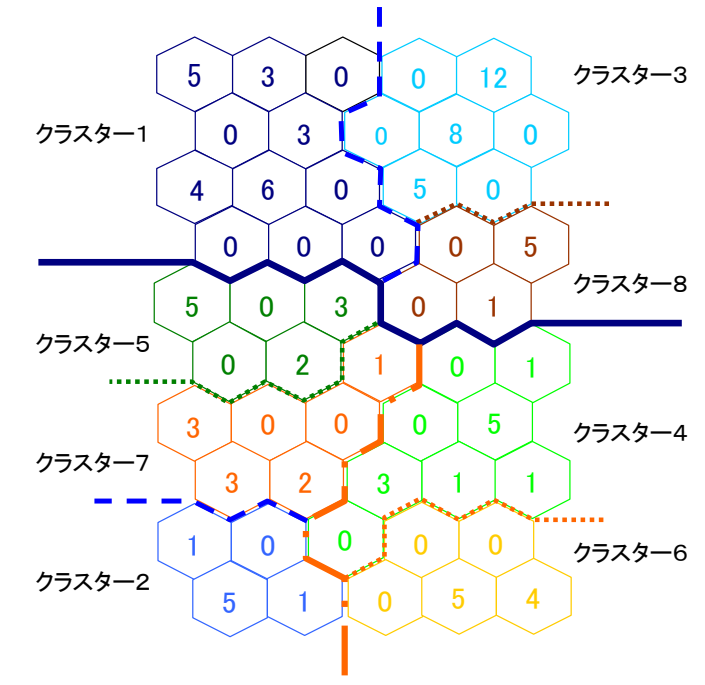

図-6 クラスター配置とノード分類結果（数值 : 観測井数）

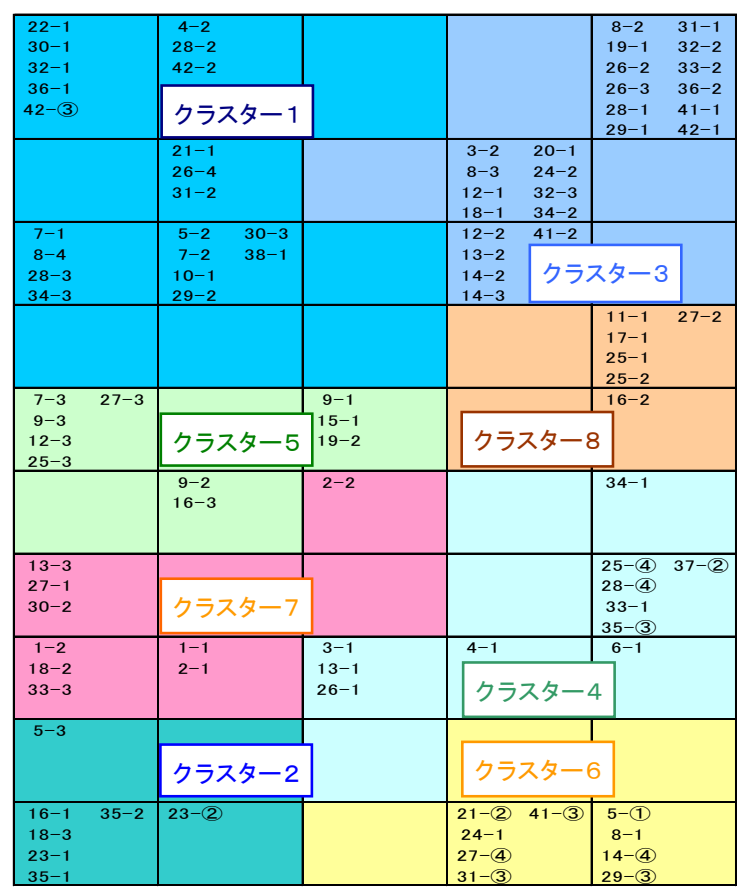

図-7 各クラスターのノードに分類された観測井(番号)

次いで，図-7及び図-8に示すクラスター毎の主な変 動特性を記す。クラスター1は，地震直後に大きく水位 低下を生じ，翌日までにほぼ地震前の水位まで回復，14 日までに水位上昇して31日に至る高い水位を継続，ス卜 レーナ深度が中間的なパターンである。 クラスター 2 は 地震直後に大きく水位低下，翌日まで低下傾向を継続， 14日には地震前水位を若干下回る程度に回復して31日ま で継続し，ストレーナ深度は中間的である．クラスター 3は，11日16時に全クラスター中で最大の水位低下，翌 日に地震前の水位を上回るまでに回復後，31日まで継続 する，ストレーナ深度はやや浅い，クラスター4は，地 震直後に若干の水位上昇もしくは大きく変動せず，その 後も大きな変動がない状況を継続し，ストレーナ深度は かなり浅い.クラスター5は地震直後に大きく水位低下, 

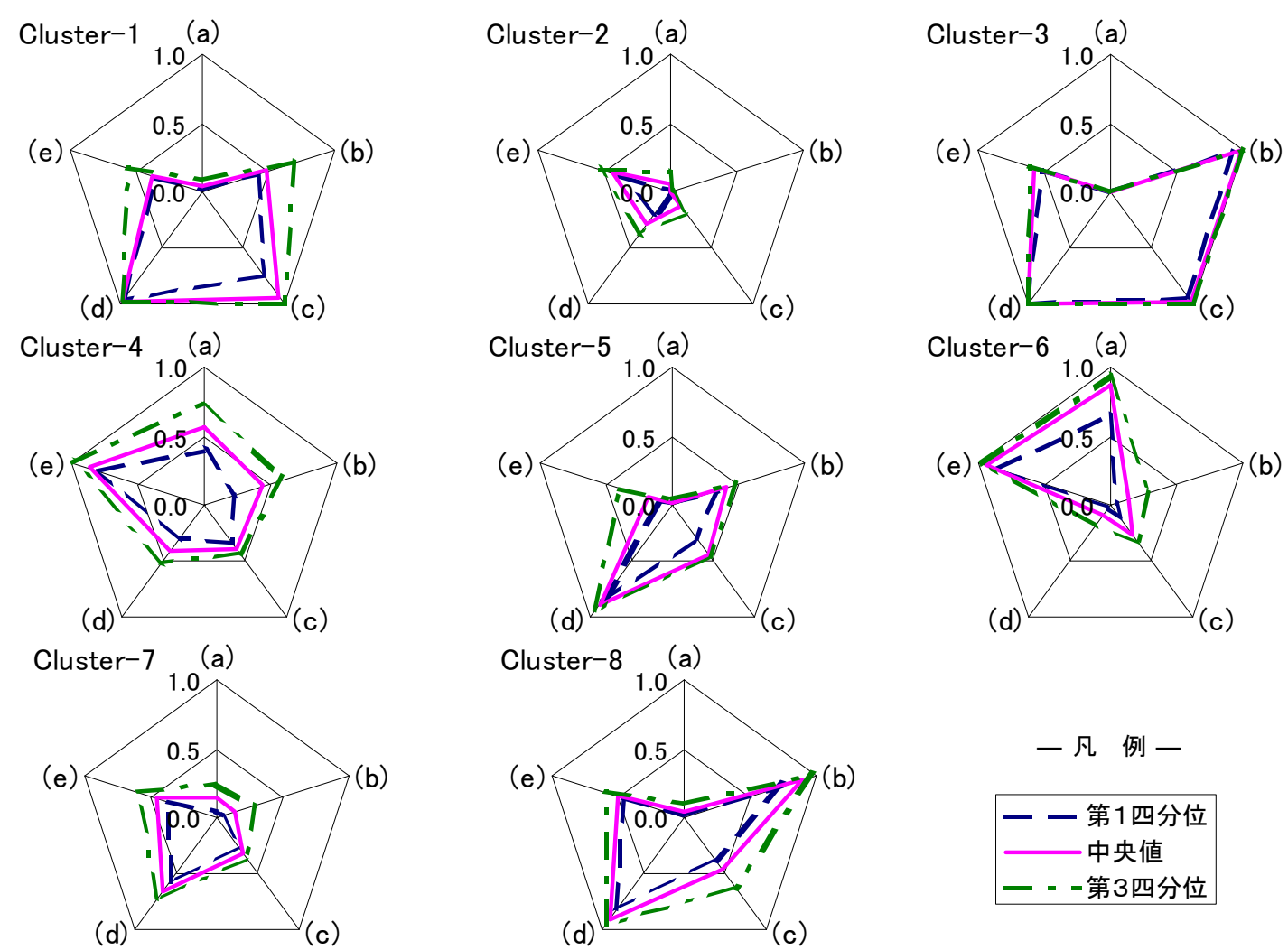

図-8 クラスター毎の水位差 (a) (d) と井戸深度 $(e)$ の分布特性

翌日までにほぼ地震前の水位に回復し，14日まで継続し た後に31日まで上昇, ストレーナ深度は若干深い. クラ スター6は，地震直後に水位上昇もしくは大きな変動が なく, 翌日までに地震前より水位低下，14日までに地震 前と同程度に水位回復し，31日までに再び低下寸る. ス トレーナ深度は非常に浅い. クラスター7は地震直後に 比較的大きな水位低下を生じ，翌日も同水位を維持，14 日に地震前の水位まで上昇し31日まで水位上昇を継続し， ストレーナ深度は平均的である. クラスター 8 は, 地震 直後に大きく水位低下した後に反転上昇，14日に地震前 の水位レベルまで低下し，31日まで再び上昇する，ス卜 レーナ深度は若干浅いパターンであることが判る。

\section{（2）SOMと目視による時系列変動傾向との比較検討}

当該地下水位の変動傾向に関して著者らは既に, 目視 による時系列変動のみに基づいて地下水位の変動特性を 主観的に抽出・分類（以下「主観的な分類」と記す）し た結果，大きく被圧地下水を7パターン，不圧地下水を3 パターンに分類できることを明らかにした7)．以下では， 先の主観的な分類結果と今回のSOMによる分類結果に ついて比較検討を試みる.

表-2には, 先の主観的な分類に基づく地下水位の変動 パターンに関し，その記号と共に特徵・観測井数を示し た. また表-3は, 今回のSOMによる8つのクラスターに 属する表-2の変動パターンを示したものである. 先の主 観的な分類では, 被圧・不圧地下水を別々に分類した結 果，合計10パターンとなっているが，SOMでは被圧・
不圧地下水を区別せず，8パターンに分類している.

SOM と先の主観的な分類の結果に相違が生じた主な 要因は, 先の分類結果が地震直後の水位変動傾向と 31 日 の水位に着目してパターン分類したのに対し，SOMで は基淮化した個々のデータを用い，ストレーナ深度を加 味して解析した点にある。 その結果, SOMでは主観的 な分類で地震直後に水位低下した被圧地下水の 3 分類 $(\mathrm{C}-$ D)が7クラスターに，不厓地下水の上昇傾向(U-I)を2ク ラスターに, 大きな変動なし $(\mathrm{U}-\mathrm{N} \cdot \mathrm{C}-\mathrm{N})$ が3クラスター に配置され，全体で8つのクラスターに分類されている. ここで，表-3より各クラスターには，対応寸る表-2 の変動パターンが2から5パターン含まれており, 先の主 観的な分類傾向と異なるようにも見受けられる. しかし ながら, 各クラスターにおける主要な2つの変動パター ンが占める割合は，73\%から100\%と高い，例えばクラ スター4・6には, 大きな変動なしと水位上昇傾向を示寸 全不圧観測井の $80 \%$ が属している. 地震直後に水位上昇 した変動パターン(C-I·U-I)は, その後に水位の低下傾向 を有しており, 当該変動パターンが大きな変動なし(U$\mathrm{N} \cdot \mathrm{C}-\mathrm{N})$ と同一クラスターに配置されたことは，全般的 な変動傾向やストレーナ深度を考慮すれば妥当と考えら れる.さらに，クラスター1に分類されたC-DRは一時的 な水位低下後の復元傾向を示寸ため, 低下後に上昇傾向 を示すC-DIとは，31日の水位が類似傾向にあると見な すことができる．このように，SOMによる結果と先の 分類結果は, 相対的に一致した傾向にあると判断できる. 以上のとおり, 表-3及び図-8から判る全般的な特徵 
表-2 目視による被圧・不圧地下水位の変動パターン7)

\begin{tabular}{|c|c|c|c|c|c|c|}
\hline & 皮圧 & 水位変動傾向 & 井数 & 不圧 & 水位変動傾向 & 井数 \\
\hline \multirow{3}{*}{$C-D$} & C-D I & 水位低下後に反転上昇 & 42 & $U-D$ & 水位低下 & 1 \\
\hline & $C-D C$ & 水位低下し，そのまま継続 & 20 & $U-\mathrm{I}$ & 水位上昇 & 2 \\
\hline & C-DR & 水位低下後，元の水位に復元 & 13 & $\mathrm{U}-\mathrm{N}$ & 大きな変動なし & 10 \\
\hline \multirow{3}{*}{$c-I$} & C-II & 水位上昇·低下後に反転上昇 & 1 & & & \\
\hline & C-IC & 水位上昇し，そのまま継続 & 1 & & & \\
\hline & C-I D & 水位上昇後，元の水位に低下 & 1 & & & \\
\hline $\mathrm{C}-\mathrm{N}$ & $C-N$ & 大きな変動なし & 7 & & & \\
\hline
\end{tabular}

表-3 SOM解析結果に属する目視による変動パターン

\begin{tabular}{|c|c|c|c|c|c|c|c|c|c|c|c|}
\hline \multirow{2}{*}{\multicolumn{2}{|c|}{$\begin{array}{l}\text { SOMLよる分類 } \\
\text { 分類·観測井数 }\end{array}$}} & \multicolumn{10}{|c|}{ 目視による時系列変動に基づく主観的な分類 (表-2) } \\
\hline & & \multicolumn{10}{|c|}{ SOMに対応する被圧·不圧地下水の変動パターンと観測井数 } \\
\hline クラスター1 & 21 & C-D I & 12 & C-DR & 5 & C-DC & 1 & $\mathrm{C}-\mathrm{N}$ & 2 & $\mathrm{U}-\mathrm{N}$ & 1 \\
\hline クラスター3 & 25 & C-D I & 21 & C-DR & 3 & $\mathrm{C}-\mathrm{DC}$ & 1 & & & & \\
\hline クラスター8 & 6 & C-D I & 5 & $C-D C$ & 1 & & & & & & \\
\hline クラスター5 & 10 & C-DC & 5 & C-DR & 3 & C-D I & 2 & & & & \\
\hline クラスター7 & 9 & C-DC & 6 & C-DI & 2 & C-DR & 1 & & & & \\
\hline クラスター2 & 7 & C-DC & 6 & $\mathrm{U}-\mathrm{D}$ & 1 & & & & & & \\
\hline クラスター4 & 11 & $\mathrm{U}-\mathrm{N}$ & 4 & $\mathrm{C}-\mathrm{N}$ & 4 & C-I I & 1 & C-IC & 1 & C-DR & 1 \\
\hline クラスター6 & 9 & $\mathrm{U}-\mathrm{N}$ & 5 & $\mathrm{U}-\mathrm{I}$ & 2 & $C-N$ & 1 & C-ID & 1 & & \\
\hline
\end{tabular}

として，SOMによる結果は主観的な分類結果とほぼ一 致していると判断できる. また，地下水位変動の特性把 握において，SOMを用いた客観的かつ判り易いパター ン分類が可能なことを明らかにした。

\section{5. むすび}

本論文は，東京都内（島嶼・山地を除く）に存する 被圧・不圧地下水位観測42局のうち, 計画停電等による 欠測の少ない 40 局98観測井（被圧 : 85 , 不圧 : 13）にお ける5項目の観測記録を用い，パターン分類の一種であ るSOMを適用して，東日本大地震に伴う東京における 地下水位の変動パターン特性の抽出と分類を試みたもの である，その結果，地下水位の変動特性として8パター ンに分類できることを示した. SOMの結果と主観的な 分類との比較からは, SOMの成果として地下水位の変 動傾向の特徵をより客観的かつ判り易く明示できること, 全般的な分類傾向としてもほぼ一致していること等が明 らかとなった。また，SOMの適用に際しては，データ 総数に占める割合は少ないが，地震時の特徵的な地下水 位の上昇傾向を解析結果に適切に反映できるかが一つの 課題であった．SOMの解析結果としては，大きな変動 なしと同じクラスターにパターン分類されているが，他 の主要な変動傾向である水位低下とは完全に隔絶された クラスターにパターン分類されたこと，地震直後に水位 上昇した観測井についても，その後に水位低下寸る傾向 が強いことから，大きな変動なしの分類に含めることは 妥当と考えられる. その際, 入力データの指標化等によ る前処理を適切に行うことが，その特徵を明確に示すた めに重要な要素であることを明らかにできた。これらの 結果からは，地下水分野においてもSOMを用いたパ ターン解析の有意性が認められたと考える.

今後は，より多次元かつ複雑な挙動を伴う長期間に 亘る地下水位の変動特性のパターン分析において, SOMの活用を図ることにより, 東京における地下水の
変動特性の解明を進めるとともに，その変動要因との関 連性についても精査を進めて参りたい.

\section{参考文献}

1) 北川有一, 小泉尚嗣 : 東北地方太平洋沖地震(9.0)後1日間で の地下水位 - 地下水圧 - 自噴量変化, 活断層 - 古地震研究 報告, No.11, pp.309-318, 2011.

2) 産業技術総合研究所 : 東海・関東・伊豆地域における地下 水等観測結果(2010年11月～2011年5月)(43), 地震予知連絡会 会報, Vol.86, pp.458-464, 2011.

3) 板寺一洋, 菊川城司, 代田寧 : 東北地方太平洋沖地震の影 響による箱根温泉の変化, 神奈川県温泉地学研究所報告, Vol.43, pp.39-43, 2011.

4) 国分邦紀，守田優 : 地下水位変動とその影響要因との相関 について, 東京都土木技術研究所年報, 昭和59年, pp.251260, 1984.

5) 東京都環境局 : 東京都の地盤沈下と地下水の再検証につい て一平成22年度地下水対策検討委員会のまとめ一, 2011

6) 東京都 : 地震時における地下水変動に関する研究, 東京都 防災会議地震部会調查研究報告書, 1979.

7) 石原成幸, 河村明, 天口英雄, 高崎忠勝, 川合将文 : 東北 地方太平洋沖地震に伴う東京における不圧・被圧地下水位 の変動特性, 土木学会論文集B1（水工学）, Vol.68, No.4, pp.I_595-I_600, 2012.

8) 横田いずみ, 井料隆太, 井芹慶彦, 広城吉成, 神野健二: 自己組織化マップを用いた福岡市民の水に関するアンケー 卜調査結果分析, 土木学会水工学論文集, Vol.53, pp.553-558, 2009.

9) Hentati, A., Kawamura, A., Amaguchi, H. and Iseri, Y.,: Evaluation of sedimentation vulnerability at small hillside reservoirs in the semi-arid region of Tunisia using the Self-Organizing Map, Geomorphology ., No.122, pp.56-64, 2010.

10) 西山浩司, 遠藤伸一, 神野健二, 河村明 : 自己組織化マッ プを利用した梅雨期特有の気象場の分類, 土木学会水工学論 文集, Vol.49, pp.241-246, 2005.

11) Jin, Y. H., Kawamura, A., Park, S. C., Nakagawa, N., Amaguchi, H. and Olsson, J., : Spatiotemporal classification of environmental monitoring data in the Yeongsan River basin, Korea, using selforganizing maps, Journal of Environmental Monitoring, No.13, pp.2886-2894, 2011.

12) 東京都土木技術支援・人材育成センター: 平成 23 年度 水 準基標測量(その1・2) (区部)，一級水準測量成果表，2012.

13) Scott, K. E. and Oyana, T. J., : An improved algorithm for segregating large geospatial data, $9^{\text {th }}$ AGILE Conference on Geographic Information Science, pp.177-185, 2006.

14) Leloup, J. A., Lachkar, Z., Boulanger, J. P.and Thiria, S., : Detecting decadal changes in ENSO using neural networks, Climate Dynamics, Vol.28, pp.147-162, 2007

(2012. 9. 30受付) 